\title{
The Effect of a Ruminal Nitrogen (N) Deficiency in Dairy Cows: Evaluation of the Cornell Net Carbohydrate and Protein System Ruminal N Deficiency Adjustment ${ }^{1}$
}

\author{
R. Ruiz, ${ }^{* 2}$ L. O. Tedeschi, ${ }^{\star}$ J. C. Marini, ${ }^{*}$ D. G. Fox,${ }^{*}$ A. N. Pell, ${ }^{*}$ G. Jarvis, $\dagger$ and J. B Russell \\ *Department of Animal Science and †Section of Microbiology, Cornell University, Ithaca, NY 14853, and \\ fU.S. Plant, Soil and Nutrition Laboratory and U.S. Dairy Forage Research Center, ARS, USDA, Ithaca, NY 14853
}

\begin{abstract}
Twenty-four multiparous and fifteen first lactation Holstein cows averaging 263 days in milk and weighing $614 \mathrm{~kg}$ were fed diets adequate or deficient in ruminal nitrogen $(\mathrm{N})$, based on predictions of the Cornell Net Carbohydrate and Protein System (CNCPS). After adjustment to a low crude protein $(\mathrm{CP})$ total mixed rations (TMR; $12.6 \% \mathrm{CP}$ ), the cows were allocated to 13 blocks based on lactation number, milk production, body condition score, and body weight. Within each block, cows were randomly assigned to one of the 3 treatment (TRT) diets $(9.4,11.1$ and $14.1 \% \mathrm{CP}$ for TRT 1,2 , and 3, respectively). All diets contained the same proportion of high moisture corn, chopped grass hay, and minerals, with urea substituted for corn silage as needed to reach the three CP levels. The TRT diets were then fed to the cows for $4 \mathrm{wk}$. Milk production was significantly affected by TRT: $15.5,18.8$, and $21.7 \mathrm{~kg} / \mathrm{d}$ for TRT diets 1,2 , and 3 , respectively. DMI was increased significantly as the percentage of CP increased from 9.4 to $14.1 \%$ CP: 17.6, 20.0 , and $21.2 \mathrm{~kg} / \mathrm{d}$ for TRT diets 1,2 , and 3 , respectively. CNCPS predictions for production (with and without the $\mathrm{N}$ adjustment for ruminal $\mathrm{N}$ deficiency) of metabolizable protein (MP) allowable milk were compared with observed milk production. Using the average individual weekly cow data from all 3 TRT, we found that the CNCPS accounted for 72 and $68 \%$ of the variation in MP allowable milk without and with the $\mathrm{N}$ deficiency adjustment, respectively. The overall mean bias without the $\mathrm{N}$ adjustment was $3.3 \mathrm{~kg}$ of milk (over prediction model bias of $14.6 \%, P<0.001$ ), and the $\mathrm{N}$ adjustment reduced the model over-prediction bias to $0.01 \mathrm{~kg}$ of milk $(P=0.96)$.
\end{abstract}

\footnotetext{
Received July 12, 2001.

Accepted April 20, 2002.

Corresponding author: D. G. Fox; e-mail: dgf4@cornell.edu.

${ }^{1}$ Mention of trade names, proprietary products, or specific equipment does not constitute a guarantee or warranty of the product by the USDA and does not imply its approval to the exclusion of other products that also may be suitable.

${ }^{2}$ Current address: Poulin Grain Inc., 24 Railroad Square, Newport, VT 05855. Phone: (802)334-6731, E-mail: rr44@cornell.edu.
}

(Key words: CNCPS, dairy cow, ${ }^{15} \mathrm{~N}$ kinetics, ruminal nitrogen deficiency)

Abbreviation key: CNCPS = Cornell Net Carbohydrate and Protein System, eNDF = effective NDF, GER $=$ Gastrointestinal Entry Rate, GIT = gastrointestinal tract, $\mathbf{H M C}=$ high moisture corn, $\mathbf{M P}=$ metabolizable protein, $\mathbf{M U U N}=$ milk and urinary urea nitrogen, $\mathbf{M U N}$ = milk urea nitrogen, NDS $=$ neutral detergent soluble, pTMR = pretrial TMR, PUN = plasma urea nitrogen, $\mathbf{R N B}=$ ruminal nitrogen balance, $\mathbf{U E R}=$ urea-N entry rate, $\mathbf{U U N}=$ urinary urea-N.

\section{INTRODUCTION}

Many experiments in which NPN has been added to high forage diets have yielded inconclusive results, and only small responses have been obtained (Ørskov, 1992). Animal responses to dietary NPN supplements require that the $\mathrm{N}$ available in the rumen be below the microbial requirement (Van Soest, 1994). The lack of animal responses to NPN in high forage diets is likely due to a lack of available ruminally degradable carbohydrates (Van Soest, 1994), and low cell wall digestibility in mature forages (Ørskov, 1992). When ruminal $\mathrm{N}$ is deficient, fiber fermentation and microbial yield can be depressed (Hume et al, 1970). Correcting this ruminal N deficiency may result in an increase in DM digestibility with a consequent increase in food intake (Ørskov, 1992).

Most ruminal bacteria can utilize $\mathrm{NH}_{3}$ as a nitrogen source, but some can be stimulated by peptides and amino acids (Allison, 1969). The amino acid and peptide stimulus effect varies, however, and may depend upon the degradability of the energy source (Cruz Soto et al., 1994). The Cornell Net Carbohydrate and Protein System (CNCPS) 3.0 had a peptide stimulation adjustment that enhanced microbial yield by as much as $17 \%$, but did not have a provision for $\mathrm{N}$-deficiency per se. In version 4.0 of the CNCPS (Fox et al., 2000), the predictions of fiber digestion and production of microbial mass from ruminal degradation of carbohydrates are adjusted when ruminal $\mathrm{N}$ is deficient (Tedeschi et al., 2000). While the rate of digestion of feeds may decrease due to a 
ruminal N deficiency (Mehrez et al., 1977; Erdman et al., 1986), data to mechanistically model a change in the rate of digestion of the CNCPS carbohydrate fractions are not currently available. Recent work has indicated that ruminal bacteria that do not digest fiber can spill energy when amino $\mathrm{N}$ is lacking and carbohydrates are in excess, but some of the decrease in apparent growth efficiency can be explained by the effect of amino $\mathrm{N}$ on growth rate (Van Kessel and Russell, 1996). When these same ruminal bacteria have only ammonia, growth is slower and they must devote a large fraction of their energy to maintenance functions (Russell and Strobel, 1993). In early versions of the CNCPS, bacterial growth was driven exclusively by the ratio of carbohydrate fermentation, and the peptide stimulation function could not accommodate both energy loss and the effect of amino $\mathrm{N}$ on bacterial growth rate (Russell et al., 1992).

CNCPS 4.0 (Fox et al., 2000) has equations that adjust microbial yield and fiber digestion when ruminal $\mathrm{N}$ is deficient (Tedeschi et al., 2000). Data for lactating dairy cattle were lacking, however, and the model was only evaluated for experiments involving growing cattle.

The objective of this experiment was to evaluate the CNCPS adjustments of ruminal microbial protein production and fiber digestion in animals fed high forage diets, using data on the performance of lactating dairy cattle sensitive to dietary $\mathrm{N}$ supplementation.

\section{MATERIALS AND METHODS}

\section{General}

This experiment was conducted at the Teaching and Research Center at Cornell University during the fall of 1999. Twenty-four multiparous and fifteen first lactation Holstein cows averaging 263 DIM, and $614 \mathrm{~kg}$ BW were used in this study. Before the beginning of the experiment, the diets were gradually changed from the farm's TMR to a low CP TMR [pretrial TMR (pTMR)] during a $12 \mathrm{~d}$ transition period. The TMR DMI was measured during the 5 days before the transition period. During the $12 \mathrm{~d}$ transition period, the amount of TMR was decreased incrementally, and the amount of pTMR was increased. During the $12 \mathrm{~d}$ transition period, cows were offered a ration of 35:65, 60:40, and 80:20 of pTMR:TMR for 6,4 , and 2 days, respectively. By the end of the transition period, the TMR was completely replaced by the pTMR. The pTMR then was fed to the cows during a $13 \mathrm{~d}$ period (pre-trial period). After $10 \mathrm{~d}$ on the pTMR diet, all cows were blocked (13 blocks, 3 cows each) based on lactation number, milk production, BCS, and BW. Within each block, cows were randomly assigned to one of the three treatment diets. The treatment diets were provided for 4 weeks (lactation trial). Rumen fistulas had been previously fitted to nine of the cows in accor-
Table 1. Diet ingredients used for pre-trial (P) and trial treatment $\operatorname{diets}(1,2 \text {, and } 3)^{1}$

\begin{tabular}{lrrrr}
\hline & \multicolumn{4}{c}{ Diet } \\
\cline { 2 - 5 } Feedstuff & $\mathrm{P}^{2}$ & $1^{3}$ & $2^{4}$ & $3^{5}$ \\
\cline { 2 - 5 } & 47.5 & 48.6 & 47.9 & 46.8 \\
Corn silage & 27.4 & 27.5 & 27.4 & 27.4 \\
High moisture shelled corn & 22.0 & 22.0 & 22.0 & 22.0 \\
Grass hay & 1.2 & 0.0 & 0.7 & 1.8 \\
Urea & 0.5 & 0.5 & 0.5 & 0.5 \\
Calcium sulfate & 0.4 & 0.4 & 0.4 & 0.4 \\
Dicalcium phosphate & 0.1 & 0.1 & 0.1 & 0.1 \\
Magnesium oxide & 0.3 & 0.3 & 0.3 & 0.3 \\
Calcium carbonate & 0.4 & 0.4 & 0.4 & 0.4 \\
Salt & 0.2 & 0.2 & 0.2 & 0.2 \\
Premix & 6
\end{tabular}

${ }^{1}$ All values expressed on a dry matter basis.

${ }^{2}$ Designed to have $11 \% \mathrm{CP}$.

${ }^{3}$ Designed to have $8 \% \mathrm{CP}$.

${ }^{4}$ Designed to have $10 \% \mathrm{CP}$.

${ }^{5}$ Designed to have $13 \% \mathrm{CP}$.

${ }^{6}$ Composition: $1.98 \% \mathrm{Mn}, 1.98 \% \mathrm{Zn}, 0.97 \% \mathrm{Fe}, 0.43 \% \mathrm{Cu}, 0.04 \% \mathrm{I}$, $0.04 \%$ Co, $0.01 \%$ Se. $2,600,000 \mathrm{IU} / \mathrm{kg}$ of vitamin A, $1,060,000 \mathrm{IU} / \mathrm{kg}$ of vitamin D, 8,800 IU/kg of vitamin $\mathrm{E}$.

dance with procedures approved by the Cornell Institutional Animal Care and Use Committee.

\section{Housing and Feeding Management}

All diets fed to ad libitum intake. The cows were housed in individual stalls, and were milked at 1130 and $2330 \mathrm{~h}$. Water was provided at all times from automatic water bowls. All diets (Table 1) were prepared daily, and contained the same proportion of high moisture corn (HMC), chopped grass hay, and minerals with urea substituted for corn silage as needed to reach 8,10 , and $13 \% \mathrm{CP}$ (treatment diets 1, 2 and 3, respectively). Cows were fed at 0800 . The amounts of minerals and vitamins supplied were based on NRC recommendations. Because a sulfur deficiency limits NPN utilization (Bouchard and Conrad, 1973), calcium sulfate was added to produce diets containing $0.20 \%$ sulfur. The amount of feed offered was adjusted to yield approximately $10 \%$ orts. The DM of individual diet feed ingredients was determined three times per week using a microwave drying oven to obtain data for this calculation.

\section{Model Evaluation}

The evaluation of the CNCPS model was conducted with the data from the lactation trial, and the analysis was performed using weekly data from the measured DMI of each individual cow. Feed samples were combined by week for analysis by wet chemistry analysis, and the production data (milk volume and milk components) for each cow were averaged weekly. 
The adjustment in $\mathrm{N}$ only modifies the predictions of fiber digestion and microbial protein synthesis if the ruminal $\mathrm{N}$ balance [RNB (percentage of $\mathrm{N}$ required predicted by the CNCPS)] is under $100 \%$ (Tedeschi et al., 2000). In order to determine the RNB in the CNCPS, the potential microbial growth from ruminally degraded fiber and nonfiber carbohydrates is computed. If fermentable energy is the first limiting nutrient, microbial protein production is dictated by energy. If, however, ruminal $\mathrm{N}$ is limiting (RNB is under $100 \%$ ) a reduction in fiber carbohydrate bacterial yield and fiber carbohydrate digestion is computed.

\section{Sampling, Collection and Analysis}

General. Milk production was recorded daily at 1130 and 2330. Milk samples were collected at each milking. Samples were preserved with 2-bromo-2-nitropropane1, 3 diol and were analyzed for fat, protein, milk urea nitrogen (MUN), and SCC at the New York DHIA milk testing laboratory (infrared analysis; Foss 605B MilkoScan; Foss Electric, Hillerod, Denmark). On days 16, 17, 18,19 , and 20 of the lactation trial, milk sub-samples were also analyzed for MUN by manual urease/Berthelot determination (Sigma urea nitrogen procedure no. 640, Sigma Diagnostic, St. Louis, MO). All cows were bled from the coccygeal vein $3 \mathrm{~h}$ after the morning feeding during the last day of each of the 4 weeks of the lactation trial. Samples were immediately placed on ice, and subsequently centrifuged at $3000 \times g$ for $15 \mathrm{~min}$ at $4^{\circ} \mathrm{C}$. Then, plasma was collected and stored at $-20^{\circ} \mathrm{C}$. Plasma was analyzed for urea N (PUN) using a Technicon autoanalyzer (Technicon Instruments Corporation, Tarrytown, NY) using the diacetyl monoxime method of Marsh et al. (1965).

During the pre-trial and lactation trials, DMI was measured daily by weighing feed offered and refused. Samples of the diet and orts were dried at $60^{\circ} \mathrm{C}$ in a forced-air oven for $48 \mathrm{~h}$ to determine DM. During the lactation trial, all diet feed ingredients were sampled weekly. Corn silage and HMC samples were frozen in liquid nitrogen, stored at $-20^{\circ} \mathrm{C}$, and subsequently freeze-dried. Feed samples (corn silage, HMC, and hay) were ground to pass a $1 \mathrm{~mm}$ screen in a Wiley mill (Model 4, Arthur H. Thomas Co. Philadelphia, PA). Samples were combined for each week. All feed samples were analyzed for Kjeldahl $\mathrm{N}$ using boric acid in the distillation flasks (Pierce and Haenisch, 1947), NDF with sodium sulfite and $\mathrm{ADF}$, and acid detergent lignin (Van Soest et al., 1991). All protein fractions, buffer-soluble protein, NPN, ADIN, and neutral-detergent insoluble N were determined according to the procedures of Licitra et al. (1996). Ash and ether extract were analyzed according to the AOAC (1990). The digestion kinetics of the carbohydrate fractions of the hay, HMC, and corn silage were determined with the gas production procedure as described by Pell and Schofield (1993). The rate of digestion of the neutral detergent soluble (NDS) fractions in the hay (combined carbohydrate fractions A and B1) were measured using a curve subtraction technique with in vitro gas production data from the whole forage and the isolated neutral detergent extracted fiber (Schofield and Pell, 1995). The in vitro fermentation of the HMC was conducted with fresh samples, and because of the low gas contribution of the corn B2 fraction, the HMC B2 digestion rate value used was that obtained by Chen et al. (1999). The B2 digestion rate value of the corn silage was obtained from the isolated corn silage neutral detergent extracted fiber fermentation, and the value assigned to the corn silage $\mathrm{A}+\mathrm{B} 1$ digestion rate fraction was the value obtained from the HMC.

Digestion and nitrogen balance trial. The 9 ruminally fistulated cows (3 cows per treatment) were kept in metabolism stalls, and a 7-d fecal-urine collection period was conducted during d 17 to 23 of the lactation trial. Feed offered and samples of the orts were collected for each cow. Samples were dried at $60^{\circ} \mathrm{C}$ in a forced-air oven for $48 \mathrm{~h}$ for DM determination. Samples were subsequently ground to pass a $1 \mathrm{~mm}$ screen in a Wiley mill, and combined by volume across the 7-d period. Samples were analyzed for NDF and Kjeldahl $\mathrm{N}$ as described previously.

Urine was collected from the nine fistulated cows via a Foley catheter. In order to assess the amount of acid needed to bring urinary $\mathrm{pH}$ to 3 , urine samples were collected by eliciting micturition by manual stimulation of the vulva $1 \mathrm{~d}$ before the catheters were inserted. Urine was collected twice daily in buckets with $350 \mathrm{ml}$ of $20 \%$ $\mathrm{H}_{2} \mathrm{SO}_{4}$. Each morning at the end of a 24 -h period, the two collections were mixed, and a daily sample (1\% of volume) was collected, and stored at $-20^{\circ} \mathrm{C}$. Samples were thawed, subsequently combined by cow, and analyzed for Kjeldahl $\mathrm{N}$ as described previously.

Feces were collected every $24 \mathrm{~h}$. A daily sample (3\% of volume on a wet matter basis) was collected and stored at $-20^{\circ} \mathrm{C}$. After the experiment was completed, fecal samples were thawed, combined by cow, and analyzed for $\mathrm{DM}, \mathrm{NDF}$, and Kjeldahl N (on wet samples) as previously described.

The amount of $\mathrm{N}$ in the milk was calculated from DHIA milk true protein data.

Ruminal fermentation, blood sampling, and in situ NDF digestibility. Ruminal fluid was collected every $3 \mathrm{~h}$ for a $48 \mathrm{~h}$ period during $\mathrm{d} 17$ to 18 of the lactation trial. Ruminal fluid was collected by suction from at least five locations in the rumen. The samples were combined (500 $\mathrm{ml}$ total) and strained through four layers of cheesecloth. A sub-sample $(50 \mathrm{ml})$ was chilled 
to $5^{\circ} \mathrm{C}$, transported to the laboratory and centrifuged at $500 \times g\left(5 \mathrm{~min}, 5^{\circ} \mathrm{C}\right)$ to remove feed particles and protozoa. The sample was then centrifuged at $10,000 \times g(15$ $\min , 5^{\circ} \mathrm{C}$ ) to remove bacteria. A portion of the clarified ruminal fluid $(10 \mathrm{ml})$ was frozen for ammonia and VFA analyses. The $\mathrm{pH}$ of the ruminal fluid was measured as described by Ruiz et al. (2001). Ammonia in cell-free ruminal fluid was measured by the colorimetric method of Chaney and Marbach (1962). Ruminal VFA were quantified by HPLC (Beckman model 334 liquid chromatograph, Model 156 refractive index detector, Model 421 CRT data controller, CR1A integrator, Bio-Rad HPX$87 \mathrm{H}$ organic acid column, 20- $\mu \mathrm{L}$ loop, $0.013 \mathrm{~N} \mathrm{H}_{2} \mathrm{SO}_{4}$, $0.5 \mathrm{ml} / \mathrm{min}, 50^{\circ} \mathrm{C}$ ).

One day before the rumen sampling period, the nine fistulated cows were catheterized in the jugular vein. While a rumen sample was taken, a blood sample from the jugular vein catheter was taken for PUN determination and analyzed as previously described.

The ruminally fistulated cows were used to measure in situ NDF digestibilies at the end of the pre-trial period and at the end of each of the 4 weeks of the lactation trial. Before the beginning of the experiment, a $7-\mathrm{kg}$ sample of the corn silage used during the trial was dried at $60^{\circ} \mathrm{C}$ in a forced-air oven for $48 \mathrm{~h}$, had its DM determined, and was subsequently ground to pass through a 4-mm screen (Wiley mill, Model 4, Arthur H. Thomas Co. Philadelphia, PA). Samples weighing approximately $5.0 \mathrm{~g}$ were placed in $10-\mathrm{cm} \times 20-\mathrm{cm}$ Dacron polyester bags with a pore size of $53 \mu \mathrm{m}$. Eight bags and a blank (empty bag) were placed in a zippered nylon mesh lingerie sack $(38 \times 46 \mathrm{~cm} ; 4 \times 6 \mathrm{~mm}$ mesh) and incubated in the rumen of each fistulated cow for $30 \mathrm{~h}$. All bags were simultaneously removed from the rumen and rinsed with cold tap water to remove material adhering to the outside of bags and to arrest microbial fermentation. The NDF was determined directly on the bag using the ANKOM ${ }^{200 / 220}$ Fiber Analyzer (ANKOM Technology Corp., Fairport, NY).

Nitrogen kinetics. On d 2 of the $\mathrm{N}$ balance, immediately after the 1130 milking, $900 \mathrm{mg}$ of double labeled urea $\left(99.2 \%{ }^{15} \mathrm{~N}\right.$, Mass Trace Inc, Woburn MA) prepared in sterile saline $(9 \mathrm{~g} \mathrm{NaCl} / \mathrm{L})$, was infused intravenously into the jugular vein as a single dose in each animal. Catheters were then flushed with saline to ensure that all the tracer had entered the animal. Urine was collected for the next $72 \mathrm{~h}$, and urea was isolated using a $2 \mathrm{ml}$ column containing a cation exchange resin (AG-50, 100-200 mesh, H+ form; Biorad, Richmond, VA). Urea was diluted to $16.6 \mathrm{mg} / \mathrm{dl}$, degassed and frozen. Rittenberg type tubes were removed from the vaccum line and $0.5 \mathrm{ml}$ of lithium hypobromite $(\mathrm{LiOBr})$, previously bubbled with $\mathrm{He}$, were added and frozen on top of the urea solution. The head space was pumped out, the stopcock closed, and the hydrolysis tube was incubated at $60^{\circ} \mathrm{C}$ for $20 \mathrm{~min}$. Under these conditions, the nonmonomolecular degradation of urea, calculated as the contribution of mass 29 when a solution of ${ }^{15} \mathrm{~N}^{15} \mathrm{~N}$ urea was (after correcting for the ${ }^{15} \mathrm{~N}^{14} \mathrm{~N}$-urea present) degraded into $\mathrm{N}_{2}$,was 6\%, similar to the observation of Sarraseca et al. (1998). The $\mathrm{N}_{2}$ resulting from urea degradation was introduced into a NC2500 Carlo Erba dual inlet elemental analyzer (Thermoquest, Milan, Italy) using a Finnigan delta plus multiport (Finnigan, San Jose, CA) and mass/charge 28, 29, and 30 were determined.

Urea-N entry rate (UER) into the urea pool was calculated from the dilution of the infused ${ }^{15} \mathrm{~N}^{15} \mathrm{~N}$ urea in the urine. Urinary urea-N (UUN) was measured using a Technicon autoanalyzer (Technicon Instruments Corporation, Tarrytown, NY) using the method of Marsh et al. (1965) and was added to the urea excreted in milk to yield excreted urea nitrogen [milk and urinary urea$\mathrm{N}$, (MUUN)]. The amount of urea-N transferred to the GI tract [Gastointestinal Entry Rate (GER)] was calculated as the difference between the amount of urea-N produced and the amount excreted in the urine and the milk (GER = UER - MUUN). The urea-N that entered the gastrointestinal tract (GIT) was hydrolyzed to ammonia, and the fraction of this $\mathrm{N}$ that returned for the synthesis of a new molecule of urea (ROC, returned to the ornithine cycle) was calculated from the ratio of ${ }^{15} \mathrm{~N}^{14} \mathrm{~N}$-urea to $\left[{ }^{15} \mathrm{~N}^{14} \mathrm{~N}+{ }^{15} \mathrm{~N}^{15} \mathrm{~N}\right]$ according to the model of Lobley et al. (2000).

\section{Statistical Methods}

For all statistical analyses, the plot of the studentized or standardized residuals against predicted values, treatments, blocks, or cows were used to identify outliers and homogeneous variance (Kuehl, 2000).

Lactation data. The lactation data were analyzed as a repeated measure design with the PROC MIXED of SAS (1999). We used the restricted maximum likelihood method to estimate the covariance parameters and the Satterthwaite method for computing degrees of freedom for tests of fixed effects in the denominator. The autoregressive order was selected to model the covariance structure. The subject was cow within treatment. The statistical model following notation is described below:

$$
\begin{aligned}
\mathrm{Y}_{\mathrm{ijk}}= & \mu+\alpha_{\mathrm{i}}+\beta_{\mathrm{j}}+\gamma_{\mathrm{k}}+\mathrm{c}(\mathrm{a})_{1 \mathrm{i})} \\
& +(\alpha \beta)_{\mathrm{ij}}+(\alpha \gamma)_{\mathrm{ij}}+(\beta \gamma)_{\mathrm{ij}}+\mathrm{e}_{\mathrm{ijk}}
\end{aligned}
$$

where $Y_{i j k l}=$ all dependent variables, $\mu$ = overall mean, $\alpha_{\mathrm{i}}=$ fixed effect of treatments, $\beta_{\mathrm{j}}=$ fixed effect of days, $\gamma_{\mathrm{k}}=$ random effect of blocks, $\mathrm{c}(\mathrm{a})_{\mathrm{I}(\mathrm{i})}=$ cow within treatment, $(\alpha \beta)_{\mathrm{ij}}=$ fixed effect of the interaction between treatment and day, $(\alpha \gamma)_{\mathrm{ik}}=$ random effect of the interaction 
between treatment and block, $(\beta \gamma)_{\mathrm{jk}}=$ random effect of the interaction between block and time, and $\mathrm{e}_{\mathrm{ijkl}}=$ identical-independent normally-distributed random error.

Additionally, treatment effects were modeled as a polynomial function of days using the PROC MIXED of SAS following the procedures outlined by (Littell et al. (1999).

Digestion, and nitrogen balance and kinetics data. The 7-d fecal-urine collection period was analyzed as a complete randomized design using the GLM procedure of SAS (1999). The treatment means were compared using the least square means (LSMeans) test. The statistical model is shown below:

$$
\mathrm{Y}_{\mathrm{ij}}=\mu+\alpha_{\mathrm{i}}+\mathrm{e}_{\mathrm{ij}}
$$

where $\mathrm{Y}_{\mathrm{ij}}=$ all dependent variables, $\mu=$ overall mean, $\alpha_{\mathrm{i}}=$ fixed effect of treatments, and $\mathrm{e}_{\mathrm{ij}}=$ identical-independent normally-distributed random error.

Rumen, PUN, and in situ NDF digestibility data. A statistical model similar to that of the lactation analysis was used to examine ruminal data $(\mathrm{pH}$, acetate, propionate, butyrate, total VFA, acetate:propionate ratio, ammonia, PUN, and indigestible NDF). The LSMeans test was used to compare treatment effects.

$$
\mathrm{Y}_{\mathrm{ijk}}=\mu+\alpha_{\mathrm{i}}+\beta_{\mathrm{j}}+\mathrm{c}(\mathrm{a})_{\mathrm{k}(\mathrm{i})}+(\alpha \beta)_{\mathrm{ij}}+\mathrm{e}_{\mathrm{ijk} \mathrm{l}}
$$

where $\mathrm{Y}_{\mathrm{ijkl}}=$ all dependent variables, $\mu$ = overall mean, $\alpha_{\mathrm{i}}=$ fixed effect of treatments, $\beta_{\mathrm{j}}=$ fixed effect of time (sampling time for the 48-h sampling period, and week number for the in situ 30-h rumen incubation), c(a) $)_{\mathrm{k}(\mathrm{i})}=$ cow within treatment, $(\alpha \beta)_{\mathrm{ij}}=$ interaction between treatment and time effects, $\mathrm{e}_{\mathrm{ijkl}}=$ identical-independent normally-distributed random error.

Carbohydrate digestion rates. The parameters related to the rate of digestion of the corn silage, hay, and HMC sample gas production curves were obtained by fitting the following equations (Mertens and Loften, 1980):

Equation 1. $\mathrm{V}=\mathrm{V}_{\mathrm{F}} \mathrm{e}^{-\mathrm{k}(\mathrm{t}-\mathrm{L})}$ when $\mathrm{t}>\mathrm{L}$ Equation $2 . \mathrm{V}=0$ when $\mathrm{t} \leq \mathrm{L}$

where:

$$
\begin{aligned}
\mathrm{V}= & \text { volume of gas }(\mathrm{ml}) \text { produced at time } \mathrm{t}, \\
\mathrm{V}_{\mathrm{F}}= & \text { volume of gas }(\mathrm{ml}) \text { from complete substrate } \\
& \text { digestion, } \\
\mathrm{k}= & \text { digestion rate constant }(\% / \mathrm{h}), \text { and } \\
\mathrm{L}= & \text { discrete lag time }(\mathrm{h}) .
\end{aligned}
$$

The parameters of equation 1 were obtained by the NLIN procedure in SAS (1999). The data used in this curve-fitting included observations from the fermentation of the unfractionated hay and fresh HMC and the isolated neutral detergent extracted fiber of the corn silage and hay samples.

Model evaluation. The objective of a model evaluation is to determine the precision (repeatability of a prediction), and accuracy (the closeness with which a prediction approaches its true value) of the model being investigated (Cochran and Cox, 1957). Accuracy, the most important characteristic of a model, can be assessed by computing the mean bias (Cochran and Cox, 1957):

$$
\text { Mean Bias }=\frac{1}{n} \sum_{i=1}^{n}\left(\text { predicted }_{i}-\text { observed }_{i}\right)
$$

A regression analysis of model predictions was conducted by regressing the observed milk production against the model predicted milk production, as described by Mayer and Butler (1993). We used the first limiting nutrient, MP allowable milk, as the model predicted milk production (Kohn et al., 1998). The slope of the regression when forced through the origin minus one has been referred to as the model bias. Because of the ambiguity of testing whether the slope of the regression differs significantly from 1 when there is much scatter around the line (Mitchell, 1997), the model bias was calculated by dividing the mean of the Y-variate minus the mean of the $\mathrm{X}$-variate by the mean of the $\mathrm{X}$-variate (Tedeschi et al., 2000). We used the following statistical measures of model precision: the regression $\mathrm{r}^{2}$, standard error (SE), and the residual plot, which is the studentized residuals plotted against regression predicted values (Mayer and Butler, 1993). Residual plots were analyzed for outliers and systematic bias (Neter et al., 1996). Regression parameters were estimated by PROC REG, and the statistical comparison between observed and predicted values was performed using the two-sample t-test (SAS, 1999) assuming unequal variances. The CNCPS evaluation was performed using feed carbohydrate digestion rates from the feed library, and from rates obtained using in vitro gas production measurements and fitting equation 1 or 1 and 2 combined.

\section{RESULTS}

The chemical composition of the treatment diets is shown in Table 2. The mean milk production and mean DMI during the pre-trial and lactation trial periods are shown in Figures 1A and 1B, respectively. Milk production was significantly $(P<0.001)$ different among treatment diets (Table 3 ). Milk protein percentage increased $(P<0.05)$ with increasing level of dietary $\mathrm{CP}$, with diet 1 differing from diets 2 and 3 . Increases in the level of dietary CP significantly resulted in increased $(P<0.01)$ 
Table 2. Chemical composition of treatment diets. ${ }^{1}$

\begin{tabular}{lrrr}
\hline & \multicolumn{3}{c}{ Diet } \\
\cline { 2 - 4 } Item & \multicolumn{1}{c}{2} & 2 & 3 \\
\hline DM, \% & 57.1 & 57.6 & 58.3 \\
NDF, \% of DM & 35.9 & 35.6 & 35.2 \\
Lignin, \% of NDF & 8.1 & 8.1 & 8.1 \\
CP, \% of DM & 9.4 & 11.1 & 14.1 \\
Sol P, \% of CP & 45.1 & 54.1 & 64.1 \\
NPN, \% of Sol P & 88.8 & 92.2 & 94.9 \\
NDIN, \% of CP & 16.5 & 13.8 & 10.8 \\
ADIN, \% of CP & 5.3 & 4.4 & 3.4 \\
Fat, \% of DM & 2.4 & 2.4 & 2.4 \\
Ash, \% of DM & 5.9 & 5.9 & 5.8 \\
Ca, \% of DM & 0.56 & 0.56 & 0.56 \\
P, \% of DM & 0.31 & 0.31 & 0.31 \\
S, \% of DM & 0.20 & 0.20 & 0.20 \\
\hline
\end{tabular}

${ }^{1}$ Values are means calculated from ingredient composition values in Table 1, based on wet chemistry analysis of 4 weekly composites of individual feed samples. Sol $P=$ soluble protein; NDIN = neutraldetergent insoluble nitrogen.

${ }^{2}$ Sulfur content was achieved as a result of adding $\mathrm{CaSO}_{4}$.

milk fat percentage in diets 2 and 3 compared to diet 1 . Using either the DHI values or the urease method, MUN values were higher $(P<0.001)$ in diet 3 than for diets 1 and 2. The DHI and the urease MUN methods differed $(P<0.001)$, with the urease method being 2.1 units higher than the DHI values. These differences, however, were diet dependent. The two methods yielded similar values for diet 1 , but the urease method was 1.9 and 4.7 units higher $(P<0.001)$ than DHI values for diets 2 and 3 , respectively (data from comparison analysis not shown). PUN values increased $(P<0.001)$ with increasing level of dietary CP. DMI was depressed by diet 1 , and no significant differences were found between diets 2 and 3.

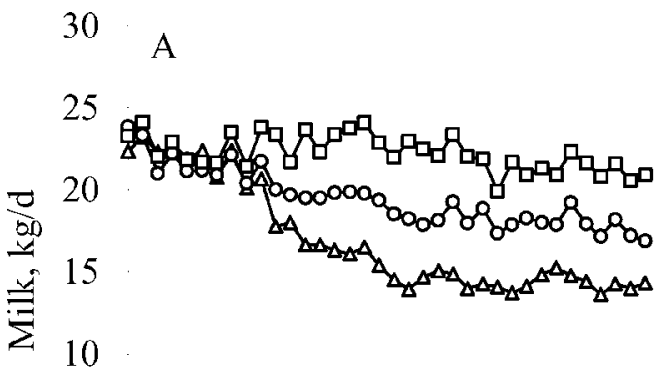

5

0

\begin{tabular}{cccccc}
-7 & 0 & 7 & 14 & 21 & 28 \\
& \multicolumn{4}{c}{ Time (days) }
\end{tabular}

Nitrogen intake, partitioning, and digestibilities are shown in Table 4. Nitrogen intake increased $(P<0.05)$ with the increasing level of dietary $\mathrm{CP}$. Urinary $\mathrm{N}$ increased $(P<0.001)$ with increasing level of dietary CP. Diets 1 and 2 did not differ $(P>0.05)$, however. Increasing the level of dietary $\mathrm{CP}$ increased the apparent $\mathrm{DM}$ and NDF digestibility $(P<0.05)$ and apparent $\mathrm{N}$ digestibility $(P<0.001)$.

The urea-N kinetics data are shown in Table 4. Urea production (UER) increased linearly $(P<0.01)$ with increasing the level of dietary protein (Table 4 ) although diet 2 did not differ $(P>0.1)$ from diet 1 . The amount of urea-N excreted in urine and milk increased quadratically $(P<0.01)$ while the proportion of urea excreted from the total produced increased linearly $(P<0.01)$. Increasing the level of protein in the diet did not change $(P=0.77)$ the total amount of urea-N recycled to the GIT. The amount of nitrogen returning for urea synthesis increased with increasing levels of protein in the diet, but the variance was high, and there were no statistical differences among dietary TRT. The proportion of GER that re-entered to the ornithine cycle increased linearly $(P<0.01)$ with increasing levels of protein.

The 48-h rumen and blood sampling data are shown in Table 5. There was no effect $(P>0.05)$ of treatment diets on ruminal $\mathrm{pH}$, and individual or total VFA concentration. Ruminal ammonia N and PUN differed $(P<$ 0.001 ) among treatment diets, and values increased as the level of dietary CP increased.

The fraction of indigestible NDF of the corn silage, determined using nylon bags in situ, is shown in Figure 2 . Treatment diets significantly affected fiber digestibility $(P<0.05)$. The overall ( 4 -week period) least square means (LSMeans) are 62.4, 61.0, and 54.2\% indigestible

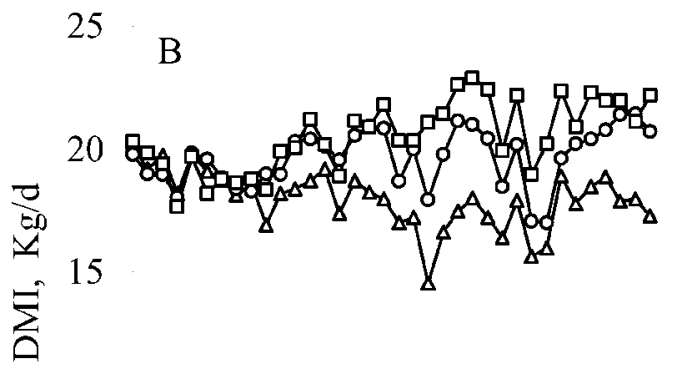

10

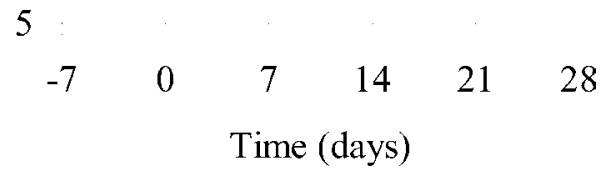

Figure 1. Effect of treatment diet on milk production (A), and dry matter intake (B). Treatments $1(9.4 \% \mathrm{CP}, \triangle), 2(11.1 \% \mathrm{CP}, \bigcirc)$, and $3(14.1 \% \mathrm{CP}, \square)$, respectively. 
RUIZ ET AL.

Table 3. Least squares means for lactation variables of treatment diets.

\begin{tabular}{|c|c|c|c|c|c|c|c|}
\hline & \multicolumn{3}{|c|}{$\operatorname{Diet}^{1}$} & \multirow[b]{2}{*}{$\mathrm{SE}$} & \multicolumn{3}{|c|}{ Significance $^{2}$} \\
\hline & 1 & 2 & 3 & & TRT & $\mathrm{T}$ & $\mathrm{T} \times \mathrm{TRT}$ \\
\hline Milk Production, kg/d & $15.5^{\mathrm{a}}$ & $18.8^{\mathrm{b}}$ & $21.7^{\mathrm{c}}$ & 1.14 & $* * *$ & $* * *(\mathrm{Q})$ & $* * *(\mathrm{Q})$ \\
\hline Fat, \% & $3.67^{\mathrm{a}}$ & $4.18^{\mathrm{b}}$ & $4.10^{\mathrm{b}}$ & 0.12 & $* * *$ & $* *(\mathrm{Q})$ & $\mathrm{NS}$ \\
\hline Protein, \% & $3.32^{\mathrm{a}}$ & $3.52^{\mathrm{b}}$ & $3.56^{\mathrm{b}}$ & 0.08 & $*$ & $* * *(\mathrm{~L})$ & NS \\
\hline MUN DHI, mg/dl & $5.3^{\mathrm{a}}$ & $6.3^{\mathrm{a}}$ & $9.4^{\mathrm{b}}$ & 0.54 & $* * *$ & $* * *(\mathrm{Q})$ & $* *(\mathrm{Q})$ \\
\hline MUN (urease), mg/dl & $4.8^{\mathrm{a}}$ & $6.3^{\mathrm{a}}$ & $14.0^{\mathrm{b}}$ & 0.67 & $* * *$ & $* * *(\mathrm{Q})$ & $* *(\mathrm{Q})$ \\
\hline PUN, mg/dl & $2.5^{\mathrm{a}}$ & $4.5^{\mathrm{b}}$ & $11.6^{\mathrm{c}}$ & 0.27 & $* * *$ & $*(\mathrm{Q})$ & NS \\
\hline Total DMI, kg/d & $17.6^{\mathrm{a}}$ & $20.0^{\mathrm{b}}$ & $21.2^{\mathrm{b}}$ & 0.79 & $*$ & $* * *(\mathrm{Q})$ & $* *(\mathrm{Q})$ \\
\hline
\end{tabular}

${ }^{1}$ Treatment effects within rows with different letter superscripts differ $(P<0.05)$.

${ }^{2} \mathrm{TRT}=$ treatment; $\mathrm{T}=$ time, as day number. $\mathrm{L}=$ linear; $\mathrm{Q}=$ quadratic; $\mathrm{NS}=$ non significant; $\mathrm{PUN}=$ plasma urea nitrogen; MUN = milk urea nitrogen.

$* P<0.05$.

$* * P<0.01$

$* * * P<0.001$.

NDF in corn silage for treatment diets 1,2 , and 3 , respectively. The time effect (week number) excluding the pretrial data was significantly $(P<0.001)$ quadratic, and there was no interaction between time and treatment effect. The CP of dietary ingredients varied throughout the lactation trial. While the variance of the corn silage and HMC CP content throughout the lactation trial was low $(9.4 \pm 0.3 \% \mathrm{CP}$, and $8.7 \pm 0.5 \% \mathrm{CP}$; respectively) the variance of the hay $\mathrm{CP}$ content was high $(8.3 \pm 1.5 \%$ $\mathrm{CP}$ ), and therefore, the variable $\mathrm{CP}$ may explain the variation in the indigestible $\mathrm{NDF}$ values by week.

The digestion parameters for the CNCPS carbohydrate fractions in each diet feed ingredient are given in Table 6. The overall CNCPS predictions of performance using feed carbohydrate digestion rates obtained using in vitro gas production measurements (rates obtained

Table 4. Diet digestibility, efficiency of $\mathrm{N}$ utilization, and $\mathrm{N}$ kinetics. ${ }^{1}$

\begin{tabular}{|c|c|c|c|c|c|}
\hline & \multicolumn{3}{|c|}{ Diet $^{2}$} & \multirow[b]{2}{*}{ SE } & \multirow[b]{2}{*}{$P$ value } \\
\hline & 1 & 2 & 3 & & \\
\hline DMI, kg/d & 16.8 & 19.9 & 20.0 & 1.7 & 0.39 \\
\hline Total N intake, g/d & $258.5^{\mathrm{a}}$ & $364.3^{\mathrm{ab}}$ & $471.7^{\mathrm{b}}$ & 40.2 & \\
\hline Fecal $N$ output, $\mathrm{g} / \mathrm{d}$ & 124.5 & 142.0 & 138.5 & 12.1 & 0.58 \\
\hline Urine $\mathrm{N}$ output, $\mathrm{g} / \mathrm{d}$ & $39.5^{\mathrm{a}}$ & $51.6^{\mathrm{a}}$ & $139.4^{\mathrm{b}}$ & 10.2 & $* * *$ \\
\hline Milk N output, g/d & 65.6 & 93.9 & 104.5 & 15.4 & 0.26 \\
\hline N Balance, $\mathrm{g} / \mathrm{d}$ & $27.3^{\mathrm{a}}$ & $75.1^{\mathrm{b}}$ & $87.6^{\mathrm{b}}$ & 12.5 & * \\
\hline \multicolumn{6}{|l|}{ Digestibility, \% } \\
\hline Apparent DM & $62.0^{\mathrm{a}}$ & $67.3^{\mathrm{b}}$ & $69.2^{\mathrm{b}}$ & 1.5 & $*$ \\
\hline Apparent N & $51.5^{\mathrm{a}}$ & $61.0^{\mathrm{b}}$ & $70.6^{\mathrm{c}}$ & 1.8 & $* * *$ \\
\hline NDF \% & $50.1^{\mathrm{a}}$ & $55.4^{\mathrm{b}}$ & $56.3^{\mathrm{b}}$ & 1.5 & $*$ \\
\hline \multicolumn{6}{|c|}{$\mathrm{N}$ partitioning, $\%$ of $\mathrm{N}$ intake } \\
\hline Fecal N & $48.5^{\mathrm{a}}$ & $38.9^{\mathrm{b}}$ & $29.4^{\mathrm{c}}$ & 1.8 & $* * *$ \\
\hline Urine $\mathrm{N}$ & $15.7^{\mathrm{a}}$ & $14.3^{\mathrm{a}}$ & $29.7^{\mathrm{b}}$ & 1.9 & ** \\
\hline Milk N & 24.6 & 25.7 & 22.1 & 3.9 & 0.8 \\
\hline \multicolumn{6}{|l|}{$\mathrm{N}$ kinetics ${ }^{3}$} \\
\hline $\mathrm{UER}, \mathrm{g} / \mathrm{d}$ & $91.6^{\mathrm{a}}$ & $130.9^{\mathrm{a}}$ & $219.9^{\mathrm{b}}$ & 27.8 & * \\
\hline MUUN, g/d & $8.6^{\mathrm{a}}$ & $25.4^{\mathrm{a}}$ & $110.5^{\mathrm{b}}$ & 11.8 & $* * *$ \\
\hline GER, g/d & 83.0 & 105.5 & 109.4 & 27.4 & 0.77 \\
\hline ROC, g/d & 13.2 & 21.0 & 35.1 & 6.2 & 0.11 \\
\hline $\mathrm{u}, \%$ & $10.1^{\mathrm{a}}$ & $22.0^{\mathrm{a}}$ & $49.9^{b}$ & 5.2 & $* *$ \\
\hline $\mathrm{r}, \%$ & $15.2^{\mathrm{a}}$ & $19.1^{\mathrm{a}}$ & $33.0^{\mathrm{b}}$ & 2.8 & $* *$ \\
\hline
\end{tabular}

${ }^{1}$ Conducted with the 9 ruminally fistulated cows.

${ }^{2}$ Treatment effects within rows with different letter superscripts differ $(P<0.05)$.

${ }^{3} \mathrm{UER}=$ Urea-N entry rate, MUUN $=$ Milk and urinary urea-N, GER $=$ Gastointestinal Entry Rate, ROC $=$ urea returned to the Ornithine Cycle, $\mathrm{u}=$ proportion of urea excreted from the total produced, $\mathrm{r}=$ proportion of GER that re-entered to the ornithine cycle.

$* P<0.05$.

$* * P<0.01$

$* * * P<0.001$. 
Table 5. Least squares means for rumen and blood treatment diet effects.

\begin{tabular}{|c|c|c|c|c|c|c|c|}
\hline \multirow[b]{2}{*}{ Measurement } & \multicolumn{3}{|c|}{$\operatorname{Diet}^{1}$} & \multirow[b]{2}{*}{$\mathrm{SE}$} & \multicolumn{3}{|c|}{ Significance $^{2}(P$ value $)$} \\
\hline & 1 & 2 & 3 & & TRT & $\mathrm{T}$ & $\mathrm{TRT} \times \mathrm{T}$ \\
\hline $\mathrm{pH}$ & 6.2 & 6.3 & 6.1 & 0.1 & 0.18 & $* * *$ & 0.21 \\
\hline Total VFA, mM & 83.4 & 72.6 & 82.4 & 4.6 & 0.23 & ** & \\
\hline Acetate, $\mathrm{m} M$ & 55.9 & 47.1 & 57.1 & 4.8 & 0.33 & $* *$ & $* * *$ \\
\hline Propionate, $\mathrm{m} M$ & 17.0 & 16.2 & 15.4 & 1.5 & 0.78 & $*$ & 0.33 \\
\hline Butyrate, $\mathrm{m} M$ & 10.6 & 9.4 & 10.3 & 1.1 & 0.73 & 0.27 & 0.29 \\
\hline Acetate:Propionate & 3.3 & 3.2 & 3.9 & 0.6 & 0.73 & 0.22 & 0.36 \\
\hline Ammonia $\mathrm{N}, \mathrm{mg} / \mathrm{dl}$ & $1.2^{\mathrm{a}}$ & $4.5^{\mathrm{b}}$ & $10.0^{\mathrm{c}}$ & 0.4 & $* * *$ & $* * *$ & * \\
\hline PUN, mg/dl & $2.6^{\mathrm{a}}$ & $5.7^{\mathrm{a}}$ & $12.3^{\mathrm{b}}$ & 1.1 & $* * *$ & $* * *$ & $* * *$ \\
\hline
\end{tabular}

${ }^{1}$ Treatment effects within rows with different letter superscripts differ $(P<0.05)$.

${ }^{2} \mathrm{TRT}=$ treatment, $\mathrm{T}=$ sampling time, $\mathrm{PUN}=$ plasma urea nitrogen.

$* P<0.05$.

$* * P<0.01$

$* * * P<0.001$.

by fitting either equations 1 and 2 combined or only using equation 1) or using the CNCPS feed library values, with or without the $\mathrm{N}$ adjustment, are shown in Table 7.

Across all treatments, the $\mathrm{N}$ adjustment reduced $(P>$ $0.05)$ the mean and model bias when the carbohydrate digestion rates from the in vitro fermentation were obtained fitting equations 1 and 2, and when the CNCPS feed library carbohydrate digestion rate values were used. Using carbohydrate digestion rates obtained from the in vitro fermentation and fitting equation 1 resulted in an under prediction of metabolism (MP) allowable milk production by the CNCPS without and with the N adjustment (Table 7). The CNCPS predicted ruminal N balance (\% of required), and treatment diet mean and model biases without and with the $\mathrm{N}$ adjustment, and with measured or feed library carbohydrate digestion rates are in Table 8 . The LSMeans for RNB (\% of required) predicted by the CNCPS differed $(P<0.0001)$ among treatment diets for either measured or feed library carbohydrate digestion rate values. The predictions of milk production by the CNCPS without and with the $\mathrm{N}$ adjustment, and with library carbohydrate digestion rates, using individual cow data throughout the lactation trial are shown in Figure 3.

\section{DISCUSSION}

In high-energy rations with ingredients of low nitrogen solubility, supplementation with urea has been shown to increase milk production in early lactation Holstein cows (Kwan et al., 1977). However, in order to achieve a positive control diet, Kwan et al. (1977) added soybean meal and brewers' grains to their diets. Therefore, the improvements in performance and digestibility might have been due to a combination of more balanced sources of dietary $\mathrm{N}$ (NH3 versus amino acids, and peptides), which improved microbial growth (Russell et al., 1992; Carro and Miller, 1999), and supply of undegradable protein. In our study, urea was the only source of $\mathrm{N}$ added to increase the CP levels of the diets, and therefore, any increases in MP allowable milk were due to an improvement in the ruminal $\mathrm{N}$ supply.

The lower DMI of treatment diet 1 compared to diets 2 and 3 could be explained by a lower DM digestibility, and due to a reduction in NDF digestibility (Table 4). Data on fiber digestibility in dairy cows consuming highly fermentable feeds and with a ruminal $\mathrm{N}$ deficiency are not available. However, ruminal $\mathrm{N}$ deficiencies in steers consuming low quality forages (Olson et al.,

Table 6. Kinetics of gas production from the in vitro fermentation data by fitting either equation 1 or equations 1 and 2, and CNCPS feed library carbohydrate digestion rates $(\% / \mathrm{h})^{1}$.

\begin{tabular}{|c|c|c|c|c|c|c|c|}
\hline \multirow[b]{2}{*}{ Sample } & \multicolumn{2}{|c|}{ Equation $1+2$} & \multicolumn{2}{|c|}{ Equation 1} & \multicolumn{3}{|c|}{ CNCPS values } \\
\hline & $\mathrm{A}+\mathrm{B} 1$ & $\mathrm{~B} 2$ & $\mathrm{~A}+\mathrm{B} 1$ & $\mathrm{~B} 2$ & $\mathrm{~A}$ & B1 & $\mathrm{B} 2$ \\
\hline Corn Silage & 24.4 & 8.6 & 13.1 & 6.1 & 10 & 35 & 6 \\
\hline Hay & 14.2 & 6.8 & 14.2 & 4.7 & 250 & 30 & 4 \\
\hline $\mathrm{HMC}^{2,3}$ & 24.4 & 11.0 & 13.1 & 9.8 & 50 & 30 & 6 \\
\hline
\end{tabular}

${ }^{1}$ For the corn silage and hay, values are means of 4 samples. The corn silage A+B1 was assumed to be the same as for the HMC A+B1.

${ }^{2} \mathrm{HMC}=$ high moisture corn.

${ }^{3}$ For the in vitro fermentation data (Equation $1+2$ and Equation 1 ) the $\mathrm{A}+\mathrm{B} 1$ digestion rate was obtained from the whole sample fermentation, and the B2 rate was from using either Equation $1+2$ or Equation 1. 


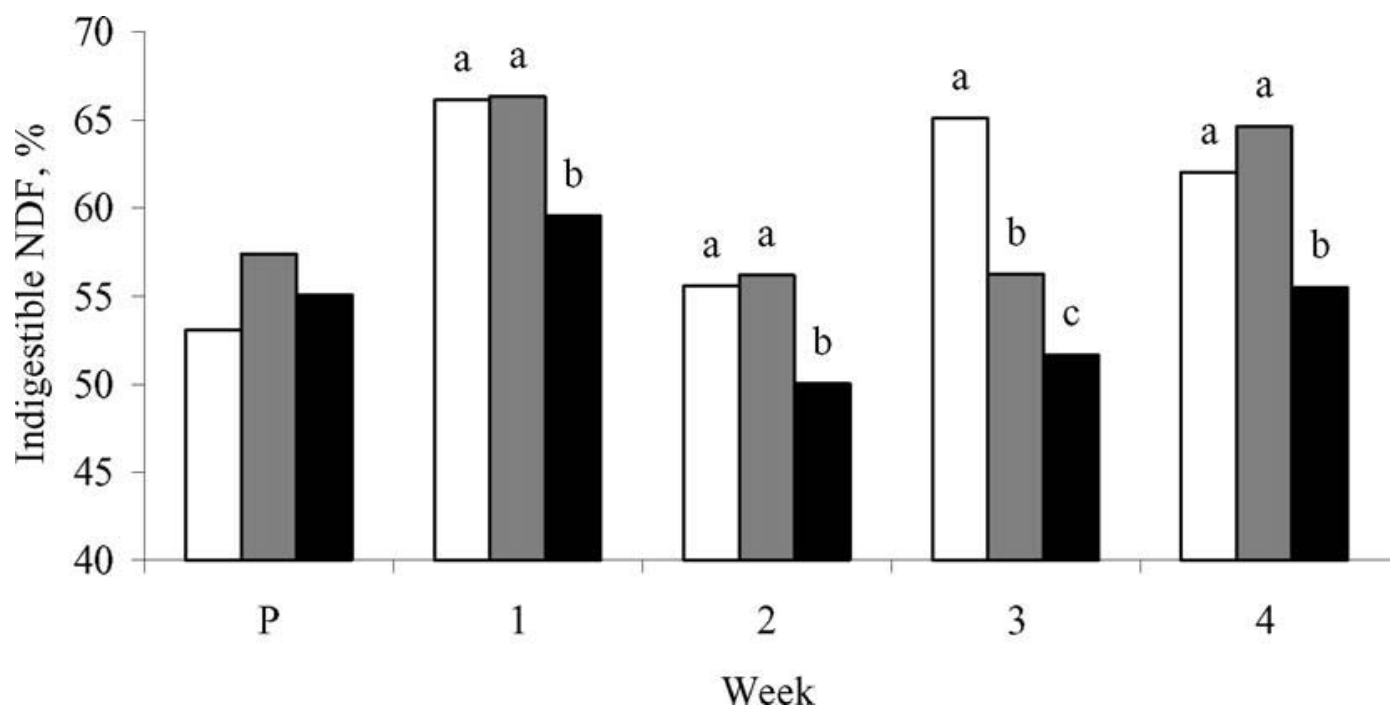

Figure 2. NDF digestibility based on in situ corn silage (32\% DM, $8.7 \%$ CP, and $43.3 \%$ NDF), 30-h rumen incubation for pretrial (P), and trial weeks. White, gray, and black columns represent treatment diets 1, 2 and 3, respectively. Columns within wk with different superscripts differ $(P<0.05)$.

1999), and goats consuming wheat straw diets (Oosting and Waanders, 1993) caused a reduction in fiber digestibility, a decrease in fiber passage rate, and a depression in DMI. Van Soest (1994) concluded that diet CP levels must be at least 6 to $8 \% \mathrm{CP}$ to satisfy the $\mathrm{N}$ requirements of ruminal bacteria on poor quality fiber diets, and that below that level, DMI and digestibility are depressed. In the present study, calculations from Table 4 show that the depression in fiber digestibility occurred at higher CP levels (9.6\% of CP). This was expected, given the higher digestibility and quality of the fiber in our diets compared to the data evaluated by Van Soest. Increased fiber digestibility of diets in the present study support a greater growth of fiber-digesting bacteria that require ammonia (Bryant, 2001).

VFA can contribute up to $70 \%$ of the caloric requirement (Bergman, 1990) in domestic ruminants such as sheep and cattle. There were no dietary treatment differences in individual and total VFA concentrations (Table
5) in the present study. Henderson et al. (1969) reported that fermentation was uncoupled from bacterial growth under $\mathrm{N}$ limited conditions. While VFA concentrations in the rumen are widely used in the literature to make inferences about ruminal fermentation, our results are in agreement with those from Dijkstra et al. (1993), which indicated that ruminal VFA concentrations might not reflect net production.

The early in vitro work of Satter and Slyter (1974) suggested that increasing ammonia $\mathrm{N}$ concentration above $5 \mathrm{mg} / \mathrm{dl}$ had no effect on microbial protein production. Further work suggested that whenever ration protein in lactating cows was higher than $12.5 \%$ or rumen ammonia $\mathrm{N}$ concentration was higher than $4 \mathrm{mg} / \mathrm{dl}$, the addition of NPN would not improve milk production (Roffler and Satter, 1975). Mehrez et al. (1977) found that the minimal ammonia concentration to maximize the rate of fermentation in sheep fed barley supplemented with different levels of urea was $23.5 \mathrm{mg} / \mathrm{dl}$. Apparently,

Table 7. Evaluation of the CNCPS N deficiency adjustment ${ }^{1}$.

\begin{tabular}{llllll}
\hline & \multicolumn{2}{c}{$\mathrm{R}^{2}$} & & \multicolumn{2}{c}{ Mean bias (kg milk) } \\
\cline { 2 - 3 } \cline { 6 - 7 } Rate & $\begin{array}{l}\text { No N } \\
\text { adjustment }\end{array}$ & $\begin{array}{l}\mathrm{N} \\
\text { adjustment }\end{array}$ & & $\begin{array}{l}\text { No N } \\
\text { adjustment }\end{array}$ & $\begin{array}{l}\mathrm{N} \\
\text { adjustment }\end{array}$ \\
\hline Equation 1 & 0.68 & 0.69 & & $-3.5^{\mathrm{a}}(22.0 \%)$ & $-3.7^{\mathrm{a}}(23.0 \%)$ \\
Equation $1+2$ & 0.72 & 0.69 & & $+3.7^{\mathrm{a}}(16.2 \%)$ & $+0.5^{\mathrm{b}}(2.8 \%)$ \\
CNCPS values & 0.72 & 0.68 & & $+3.3^{\mathrm{a}}(14.6 \%)$ & $+0.01^{\mathrm{b}}(0 \%)$ \\
\hline
\end{tabular}

\footnotetext{
${ }^{1} \mathrm{CNCPS}=$ Cornell Net Carbohydrate and Protein System. Mean bias is the average of predicted minus observed values. Letter superscripts indicate the mean bias significance.

${ }^{\mathrm{a}} P<0.001,{ }^{\mathrm{b}} P>0.05$. Model bias, in parenthesis, is the average of predicted minus observed values divided by predicted values.
} 
Table 8. Evaluation of the CNCPS N deficiency adjustment with each diet treatment ${ }^{1}$.

\begin{tabular}{|c|c|c|c|c|c|c|c|c|c|}
\hline \multirow[b]{3}{*}{ Diet } & \multirow[b]{3}{*}{$\mathrm{RNB}$} & \multicolumn{2}{|c|}{ Equation 1} & \multicolumn{3}{|c|}{ Equation $1+2$} & \multicolumn{3}{|c|}{ CNCPS } \\
\hline & & \multicolumn{2}{|c|}{ Mean bias (kg milk) } & \multirow[b]{2}{*}{ RNB } & \multicolumn{2}{|c|}{ Mean bias (kg milk) } & \multirow[b]{2}{*}{ RNB } & \multicolumn{2}{|c|}{ Mean bias (kg milk) } \\
\hline & & $\begin{array}{l}\text { No } \mathrm{N} \\
\text { adjustment }\end{array}$ & $\begin{array}{l}\mathrm{N} \\
\text { adjustment }\end{array}$ & & $\begin{array}{l}\text { No } \mathrm{N} \\
\text { adjustment }\end{array}$ & $\begin{array}{l}\mathrm{N} \\
\text { adjustment }\end{array}$ & & $\begin{array}{l}\text { No } \mathrm{N} \\
\text { adjustment }\end{array}$ & $\begin{array}{l}\mathrm{N} \\
\text { adjustment }\end{array}$ \\
\hline 1 & 99.4 & $-2.2^{\mathrm{a}}(15.0 \%)$ & $-2.8^{\mathrm{a}}(20.4 \%)$ & 77.7 & $+4.4^{\mathrm{a}}(20.8 \%)$ & $-2.4^{\mathrm{a}}(16.7 \%)$ & 76.8 & $+4.0^{\mathrm{a}}(19.3 \%)$ & $-2.9^{\mathrm{a}}(21.3 \%)$ \\
\hline 2 & 117.3 & $-3.3^{\mathrm{a}}(20.8 \%)$ & $-3.3^{\mathrm{a}}(20.8 \%)$ & 91.0 & $+3.9^{\mathrm{a}}(16.8 \%)$ & $+1.1^{\mathrm{a}}(5.3 \%)$ & 89.7 & $+3.5^{\mathrm{a}}(15.5 \%)$ & $+0.4^{\mathrm{b}}(2.1 \%)$ \\
\hline 3 & 144.1 & $-4.8^{\mathrm{a}}(29.1 \%)$ & $-4.8^{\mathrm{a}}(29.1 \%)$ & 111.0 & $+2.8^{\mathrm{a}}(11.5 \%)$ & $+2.8^{\mathrm{a}}(11.5 \%)$ & 109.8 & $+2.4^{\mathrm{a}}(9.9 \%)$ & $+2.4^{\mathrm{a}}(9.9 \%)$ \\
\hline
\end{tabular}

different substrates require different concentrations of ammonia for optimal yield (Ørskov, 1992). Using in situ fermentations, Erdman et al. (1986) concluded that the ruminal ammonia concentrations needed to maximize digestion are a function of fermentability of the diet. Odle and Schaefer (1987) reported greater demand for ruminal ammonia $\mathrm{N}$ concentrations to maximize the degradation rate of barley than that required to maximize the degradation rate of maize. In steers fed diets based on dry rolled corn ( $85 \%$ rolled corn), the supplementation of urea resulted in an increase in ruminal ammonia $\mathrm{N}$ from $6.3 \mathrm{mg} / \mathrm{dl}$ to $10.0 \mathrm{mg} / \mathrm{dl}$, and ruminal digestion was improved (Milton et al., 1997). In the present study, where a source of highly degradable carbohydrates was available, increasing ruminal ammonia $\mathrm{N}$ concentrations from $4.5 \mathrm{mg} / \mathrm{dl}$ to $10.0 \mathrm{mg} / \mathrm{dl}$ (Table 5) resulted in an improvement in ruminal NDF digestibility (Figure 2), with a consequent increase in DMI and milk production (Table 3).

In this study, the in situ corn silage 30 -h rumen incubation showed no $(P>0.05)$ overall differences in NDF digestibility between treatment diets 1 and 2 (62.4 vs. $61.0 \%$ indigestible NDF, respectively). However, treatment diet 2 had a greater total tract NDF digestibility than diet 1 (Table 4). It is possible that the 30 -h rumen incubation time might have been shorter than the actual feed retention time in the rumen, which would explain why a difference was not found. It is also possible that the higher total tract NDF digestibility in treatment diet 2 than in diet 1 might have been due to digestibility compensation in the lower gut. In cattle fed concentrates, approximately 65 to $75 \%$ of the total urea-N recycled to the GIT enters the forestomachs (Lobley et al., 2000). In the present study, there was no difference among diets in the total amount of urea-N recycled to the GIT (Table 4). However, the method used considers the gastrointestinal tract as a single compartment (Lobley et al., 2000). Because intake of diet 2 was greater than that for diet 1 (Table 3), if more nonfermented carbohydrates reached the lower digestive tract on this diet it is possible that an influx of urea-N occurred, and therefore, improved the total tract NDF digestibility (Table 4). Given that VFA are readily absorbed from the rumen as well as from all segments of the lower digestive tract (Bergman et al., 1990), an improvement in lower digestive tract fiber fermentation could yield the extra acetate needed for de novo synthesis of fatty acids (Bauman, 1976), which was reflected in a greater milk fat percentage of milk from cows fed treatment diet 2 than the treatment diet 1 (Table 3 ). Treatment diet 2 , however, had a greater milk protein percentage than treatment diet 1 (Table 3), and when MP is the first limiting nutrient, it is likely that a positive impact on milk production will result from greater amounts of microbial protein flow from the rumen. While data on $\mathrm{N}$ recycling to the gastrointestinal tract in dairy cows are lacking, it is reasonable to hypothesize that the urea-N entering the rumen compared with that entering the intestines can be affected by the carbohydrate fermentation site in the GIT. The use of more complex approaches that separate the GIT into different compartments such as rumen, small intestine, and lower digestive tract (Siddons et al., 1985) are needed in order to assess the nutritional importance of the $\mathrm{N}$ recycling to the lower digestive tract.

In the CNCPS, carbohydrates are divided into four fractions: A (sugars, short oligosaccharides, and organic acids), B1 (starch and soluble fiber), B2 (digestible fiber), and C (indigestible residue) (Sniffen et al., 1992). Because of the small size of the A fraction in corn (Chen et al., 1999) and the lack of uniformity of the NDS fraction in forages (Schofield and Pell, 1995) and in byproduct feeds (Hall et al., 1998), separate measurement of the digestion rate of the $\mathrm{A}$ and $\mathrm{B} 1$ fractions remains problematic. As a result, the digestion rate of the combined $\mathrm{A}+\mathrm{B} 1$ fraction was determined using a curve subtraction approach with data from fermentations of the whole forage and the isolated fiber extracted with neutral detergent. In the present study, the rate of digestion 
of the NDS fraction of the HMC obtained from the in vitro fermentation data was highly affected by including the fermentation data before the lag time (Table 6). This had a great impact on the prediction of milk production by the CNCPS (Tables 7 and 8). Combining equations 1 and 2 to fit the in vitro gas production measurements for the HMC resulted in a better fit than only using equation 1 (larger F-value, data not shown). The better fit obtained by combining equations 1 and 2 is due to the sigmoidal shape of the fermentation curve. While the changes in the $\mathrm{B} 2$ digestion rate of the corn silage and hay are not as large as those for the HMC (Table
6), combining equations 1 and 2 also resulted in a better fit of the fermentation data to the mathematical model due to the sigmoidal shape of the fermentation curve. The hay NDS fraction, obtained by curve subtraction, has a clear exponential shape, and no lag; therefore, its digestion rate was not affected by inclusion or exclusion of the data before the lag time (Table 6). The validity of the curve subtraction approach requires that the digestibility of the NDF fraction not be affected by the NDextraction (Schofield and Pell, 1995). While previous researchers have found either small (Schofield and Pell, 1995) or no changes (Doane et al., 1998) in fiber digest-
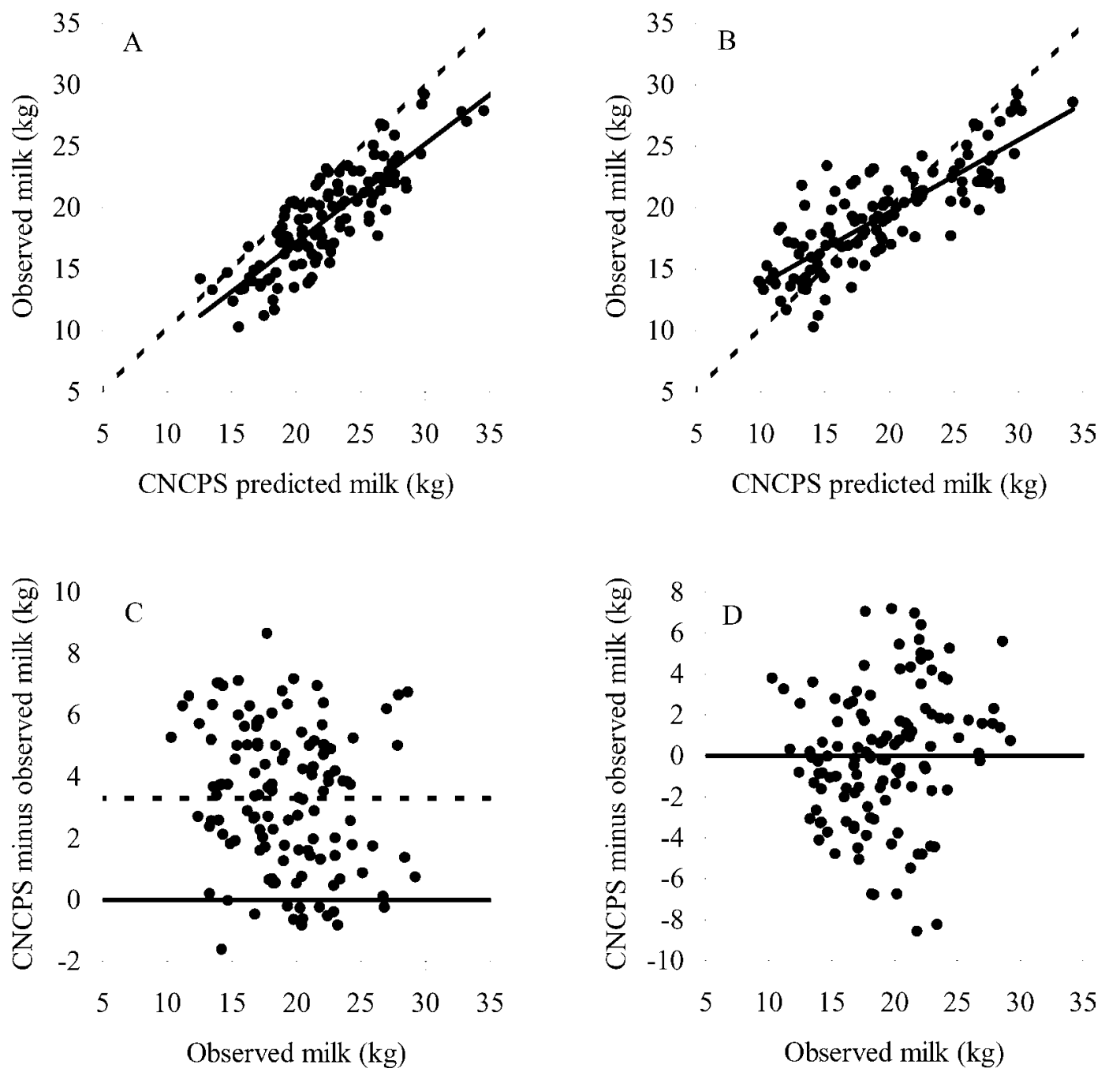

Figure 3. Prediction of milk production by the Cornell Net Carbohydrate and Protein System (CNCPS) without and with the N adjustment, and using library carbohydrate digestion rates. Labels represent the relationship between observed (o) milk (M) and CNCPS-predicted (p) milk, without (A) and with (B) $\mathrm{N}$ adjustment. The line $\mathrm{Y}=\mathrm{X}$ (dashed line) represents agreement between observed and predicted milk production. The regressions without and with the $\mathrm{N}$ adjustment are $\mathrm{M}_{0}=1.08+0.80 \times \mathrm{M}_{\mathrm{p}}\left(\mathrm{r}^{2}=0.72, \mathrm{SE}=0.19\right)$, and $\mathrm{M}_{0}=7.89+0.59 \times \mathrm{M}_{\mathrm{p}}$ $\left(\mathrm{r}^{2}=0.68, \mathrm{SE}=0.20\right)$, respectively. Deviations (CNCPS-p minus observed milk) are without $(\mathrm{C})$ and with (D) $\mathrm{N}$ adjustment vs. observed milk. The solid line represents no bias or error; the dashed line represents the mean bias. The mean biases without and with the $\mathrm{N}$ adjustment are $3.3 \mathrm{~kg}$ of milk (over prediction model bias of $14.8 \%, P<0.001$ ) and $0.01 \mathrm{~kg}$ of milk (over prediction model bias of $0.0 \%, P=0.96$ ), respectively. Data shown are for individual weeks of observations on individual cows. 
ibility after ND extraction, the extraction process increased $(P<0.001)$ the digestibility of the NDF fraction in the present study by $17.6 \%$ for the hay samples and by $9.9 \%$ for the corn silage samples. Schofield and Pell (1995) found that on average, the digestibility of the NDF fraction from clover and timothy samples increased 6.7 percentage units, which represented a $10.6 \%$ increase in digestibility of the extracted samples. The magnitude of that increase is comparable to that seen for the corn silage samples in the present study. The influence of the increase in the digestibility of the ND residue on the rate of digestion should be considered. Van Soest et al. (2000) proposed an approach for predicting fiber digestion rates; the calibration data set was limited to alfalfa and grasses, however, and further work is needed to improve and validate the proposed method.

While the rates of digestion of the $\mathrm{B} 2$ fraction in the hay and corn silage samples are similar to the CNCPS feed library values when the fermentation data before the lag time is included (Equation 1), the rate of digestion of the $\mathrm{A}+\mathrm{B} 1$ fraction of the $\mathrm{HMC}$ is more closely related to the values obtained by zeroing the fermentation data before the lag (Equation 1+2, Table 6). Because of the better fit of the exponential mathematical model to the in vitro gas fermentation data when the values before the lag time are zeroed, researchers (Schofield and Pell, 1995; France et al., 2000) have been determining the rate of degradation of ruminant feeds by zeroing the fermentation data before the lag time. In the CNCPS the rates of digestion are from in situ data (Sniffen et al., 1992) without zeroing the data before the lag. The length of the lag in vitro could be affected by the nature of the substrate fermented, the microbial species inoculated, and the amount of inoculum added (Pell and Schofield, 1993), and its existence in vivo is not certain. Forages must be chewed and ruminated extensively to reduce particle size and enable rumen microbes to penetrate feed particles and initiate digestion (Beauchemin, 1991). Ewing and Johnson (1987) concluded that both in vitro and in situ techniques underestimate ruminal starch digestion rates. The rate and extent of starch digestion depends on starch type, processing prior to ingestion, and other feedstuffs in the diet (Mills et al., 1999). Therefore, the nonuniformity of the carbohydrate fractions in feedstuffs will cause differences in the shapes of the curves from in vitro fermentation, and mathematical equations used to model the in vitro fermentation data yield different fits. While Schofield and Pell (1994) found that two bacterial growth models (logistic and Gompertz) used to fit in vitro fermentation data gave optimal fits, Dhanoa et al. (2000), using a broader set of samples, found differences between the models.

The complexity of the rumen system and the technical difficulties of estimating microbial protein synthesis have yielded few reliable predictors of either microbial protein synthesis or microbial efficiency (Dewhurst et al., 2000). Because of this problem, Firkins et al. (1998) concluded that empirical approaches to predicting microbial $\mathrm{N}$ flow to the duodenum seem likely to be more accurate than mechanistic models. In the present study, we did not measure microbial protein synthesis in the rumen, and the improvements in performance due to the expected increase in rumen microbial yield by increasing $\mathrm{N}$ availability were assessed by the animal's milk production responses, which was a sensitive test of the CNCPS rumen microbial growth model. The adjustment for $\mathrm{N}$ deficiency reduced the overprediction of milk production using the CNCPS feed library rates and when the digestion rates were obtained by excluding the fermentation data before the lag (Equation 1+2) (Table 7). When the digestion rates were obtained including the fermentation data before the lag (Equation 1) the CNCPS was already underpredicting milk production, and therefore, the $\mathrm{N}$ adjustment increased the bias towards underprediction. The $\mathrm{N}$ adjustment modifies the predictions of fiber digestion and microbial protein synthesis only if the RNB is under $100 \%$ (Tedeschi et al., 2000). The carbohydrate digestion rates dictated whether or not the CNCPS-predicted RNB was positive or negative. In Table 8, the RNB are shown on a treatment basis. Similar results are obtained when using the CNCPS feed library rates and when the digestion rates were obtained zeroing the fermentation data before the lag (Equation 1+2). While it appears that the $\mathrm{N}$ adjustment is overadjusting the predictions of milk production in treatment diet 1 , the analysis of that particular treatment had some limitations. The CNCPS uses a fixed coefficient for the efficiency of use of MP during lactation of $65 \%$, which is comparable to the $67 \%$ efficiency used in the NRC (2001). However, with $\mathrm{N}$ deficient diets, the efficiency of use of $\mathrm{N}$ can be as high as 75\% (NRC, 1985). Using an efficiency of MP of $75 \%$ for treatment diet 1 resulted in no bias for that particular treatment (data not shown). The CNCPS model overpredicted milk production in treatment diet 3 using either the CNCPS feed library rates or zeroing of the fermentation data before the lag (Equation 1+2). The origin of the over-prediction using the feed library rates came primarily from higher $\mathrm{A}$ and $\mathrm{B} 1$ digestion rate values, which suggests that they are too high for the feeds used in this study. The latter overprediction is mainly a consequence of higher B2 digestion rate values (Table 6).

The CNCPS uses an equation from the NRC(1985) to calculate rumen $\mathrm{N}$ recycling. While the method used in the current study estimates $\mathrm{N}$ recycling to the entire GIT, the NRC equation predicts $\mathrm{N}$ recycling to the rumen. The ratios between the predicted urea recycled to the rumen and the measured urea recycled to the total 
GIT were $1.24,1.22$, and 0.77 for treatment diets 1,2 , and 3 , respectively. While the value for treatment 3 falls within the range reported by Lobley et al. (2000), values for treatment diets 1 and 2 suggest that predicted $\mathrm{N}$ recycling to the rumen was greater than what was measured for the whole GIT, which implies that the equation does not accurately predict $\mathrm{N}$ recycling from $\mathrm{N}$ deficient diets fed to lactating cows.

In the CNCPS, ruminal $\mathrm{pH}$ is predicted from the effective NDF (eNDF) content of the ration, but the effect of nonfiber carbohydrate digestion rate is not considered. When diet NDF is lower than $20 \%$ of the DM, microbial yield is reduced in a linear fashion regardless of the other carbohydrates (Russell et al., 1992). Likewise, if the eNDF value of a diet is lower than $24.5 \%$ the digestibility of the B2 carbohydrate fraction is decreased for the effect of ruminal $\mathrm{pH}$ (Fox et al., 2000). According to the CNCPS the eNDF value of the treatment diets averaged $29 \%$, and therefore, there was no ruminal $\mathrm{pH}$ adjustment which meant the predicted ruminal $\mathrm{pH}$ value was 6.46 for all treatment diets. While the NDF content of the treatment diets was adequate to provide an ideal fermentation, the source of carbohydrate used was highly fermentable. Treatment diet 3 had the greatest $\mathrm{DMI}$, and ruminal $\mathrm{pH}$ was the lowest; therefore, microbial yield and the B2 carbohydrate digestibility might have been overestimated with the consequent overprediction of milk production.

\section{CONCLUSIONS}

A deficiency in ruminal $\mathrm{N}$ in lactating dairy cows can cause a decrease in rumen and total tract fiber digestibility, lower DMI, and consequently, a reduction in milk production. The CNCPS model that adjusts for a ruminal $\mathrm{N}$ deficiency accurately accounted for observed milk production. The accuracy of the adjustment, however, varied among treatment diets. While it appeared that the $\mathrm{N}$ adjustment was overadjusting the predictions of milk production in treatment diet 1 , the use of a fixed coefficient of $65 \%$ for absorbed protein utilization during lactation does not seem realistic when protein deficient diets are fed. The CNCPS overpredicted milk production when the RNB was positive; this overprediction might have been due to an overprediction of microbial yield and fiber digestibility due to an overprediction of ruminal $\mathrm{pH}$. In the present study, the ND extraction process increased the digestibility of the NDF fraction. More work is needed in order to assess the impact of that increase on the rates of digestion, as well as the mathematical model use to obtain the digestion rate values from the in vitro fermentation. While our data suggest that the NRC (1985) equation does not accurately predict $\mathrm{N}$ being recy- cled to the rumen, there are not enough data on dairy cows, thus more work is needed to confirm these findings.

\section{REFERENCES}

Allison, M. J. 1969. Biosynthesis of amino acids by ruminal microorganisms. J. Anim. Sci. 29:797-807.

Association of Official Analytical Chemists. 1990. Official Methods of Analysis. 15th ed., AOAC, Arlington, VA.

Bauman, D. E. 1976. Intermediary metabolism of adipose tissue. Fed. Proc. 35:2308-2313.

Beauchemin, K. A. 1991. Ingestion and mastication of feed by dairy cattle. Vet. Clin. North Am. Food Anim. Pract. 7:439-463.

Bergman, E. N. 1990. Energy contributions of volatile fatty acids from the gastrointestinal tract in various species. Physiol. Rev. $70: 567-590$

Bouchard, R., and H. R. Conrad. 1973. Sulfur requirement of lactating dairy cows. I. Sulfur balance and dietary supplementation. J. Dairy Sci. 56:1276-1282.

Bryant, M. P. 2001. Nutritional requirements of the predominant rumen cellulolytic bacteria. Fed. Proc. 32:1809-1813.

Carro, M. D. and E. L. Miller. 1999. Effect of supplementing a fibre basal diet with different nitrogen forms on ruminal fermentation and microbial growth in an in vitro semicontinuous culture system (RUSITEC). Br. J. Nutr. 82:149-157.

Chaney, A. L., and E. P. Marbach. 1962. Modified reagents for determination of urea and ammonia. Clin. Chem. 8:130-132.

Chen, Y. K., A. N. Pell, L. E. Chase, and P. Schofield. 1999. Rate and extent of digestion of the ethanol-soluble and neutral detergentinsoluble fractions of corn grain. J. Anim. Sci. 77:3077-3083.

Cochran, W. G., and G. M. Cox. 1957. Experimental Design. John Wiley and Sons, NY

Cruz Soto, R., S. A. Muhammed, C. J. Newbold, C. S. Stewart, and R. J. Wallace. 1994. Influence of peptides, amino acids and urea on microbial activity in the rumen of sheep receiving grass hay and on the growth of rumen bacteria in vitro. Anim. Feed Sci. Tech. 49:151-161.

Dewhurst, R. J., D. R. Davies, and R. J. Merry. 2000. Microbial protein supply from the rumen. Anim. Feed Sci. Tech. 85:1-21.

Dhanoa, M. S., S. Lopez, J. Dijkstra, D. R. Davies, R. Sanderson, B. A. Williams, Z. Sileshi, and J. France. 2000. Estimating the extent of degradation of ruminant feeds from a description of their gas production profiles observed in vitro: comparison of models. Br. J. Nutr. 83:131-142.

Dijkstra, J., H. Boer, J. Van Bruchem, M. Bruining, and S. Tamminga. 1993. Absorption of volatile fatty acids from the rumen of lactating dairy cows as influenced by volatile fatty acid concentration, $\mathrm{pH}$ and rumen liquid volume. Br. J. Nutr. 69:385-396.

Doane, P. H., A. N. Pell, and P. Schofield. 1998. Ensiling effects on the ethanol fractionation of forages using gas production. J. Anim. Sci. 76:888-895.

Erdman, R. A., G. H. Proctor, and J. H. Vandersall. 1986. Effect of rumen ammonia concentration on in situ rate and extent of digestion of feedstuffs. J. Dairy Sci. 69:2312-2320.

Ewing, D. L., and D. E. Jonhson. 1987. Corn particle starch digestion, passage and size reduction in beef steers: a dynamic model. J. Anim. Sci. 64:1194-1204.

Firkins, J. L., M. S. Allen, B. S. Oldick, and N. R. St-Pierre. 1998. Modeling ruminal digestibility of carbohydrates and microbial protein flow to the duodenum. J. Dairy Sci. 81:3350-3369.

Fox, D. G., T. P. Tylutki, M. E. Van Amburgh, L. E. Chase, A. N. Pell, T. R. Overton, L. O. Tedeschi, C. N. Rasmussen, and V. M. Durbal. 2000. The Net Carbohydrate and Protein System for evaluating herd nutrition and nutrient excretion. Animal Science Department Mimeo 213. Cornell University, Ithaca, NY.

France, J., J. Dijkstra, M. S. Dhanoa, S. Lopez, and A. Bannink. 2000. Estimating the extent of degradation of ruminant feeds from a description of their gas production profiles observed in vitro: derivation of models and other mathematical considerations . Br. J. Nutr. $83: 143-150$ 
Hall, M. B., A. N. Pell, and L. E. Chase. 1998. Characteristics of neutral detergent-soluble fiber fermentation by mixed ruminal microbes. Anim. Feed Sci. Tech. 70:23-29.

Henderson, C., P. N. Hobson, and R. Summers. 1969. The production of amylase, protease and lipolytic enzymes by two species of anaerobic rumen bacteria. Pages 189-204 in Continuous Cultivation of Microorganisms. I. Málek, K. Beran, Z. Fencl, V. Munk, J. Ricica, and H. Smrcková, ed., Academic Press, NY.

Hume, I. D., R. J. Moir, and M. Somers. 1970. Synthesis of microbial protein in the rumen. I. Influence of the level of nitrogen intake. Aust. J. Agric. Res. 21:283-296.

Kohn, R. A., K. F. Kalscheur, and M. Hanigan. 1998. Evaluation of models for balancing the protein requirements of dairy cows. J. Dairy Sci. 81:3402-3414.

Kuehl, R. O. 2000. Design of experiments: statistical principles of research design and analysis. 2nd ed. Duxbury Press, New York.

Kwan, K., C. E. Coppock, G. B. Lake, M. J. Fettman, L. E. Chase, and R. E. McDowell. 1977. Use of urea by early postpartum Holstein cows. J. Dairy Sci. 60:1706-1724.

Licitra, G., T. M. Hernandez, and P. J. Van Soest. 1996. Standardization of procedures for nitrogen fractionation of ruminant feeds. Anim. Feed Sci. Tech. 57:347-358.

Littell, R. C., G. A. Milliken, W. W. Stroup, and R. D. Wolfinger. 1999. SAS systems for mixed models. SAS Institute, Cary, NC.

Lobley, G. E., D. M. Bremmer, and G. Zuur. 2000. Effects of diet quality on urea fates in sheep as assessed by refined, non-invasive $\left[{ }^{15} \mathrm{~N}^{15} \mathrm{~N}\right]$ urea kinetics. Br. J. Nutr. 84:459-468.

Marsh, W. H., B. Fingerhut, and H. Miller. 1965. Automated and manual direct methods for the determination of blood urea. Clin. Chem. 2:624-627.

Mass, R. A., G. P. Lardy, and T. J. Klopfenstein. 1997. Modifications of the in situ NDF N method. J. Anim. Sci. 75(Suppl. 1):268(Abstr.).

Mayer, D. G. and D. G. Butler. 1993. Statistical validation. Ecol. Model. 68:21-32.

Mehrez, A. Z., E. R. Ørskov, and I. McDonald. 1977. Rates of rumen fermentation in relation to ammonia concentration. Br. J. Nutr. 38:437-443.

Mertens, D. R. and J. R. Loften. 1980. The effect of starch on forage fiber digestion kinetics in vitro. J. Dairy Sci. 63:1437-1446.

Mills, J. A. N., J. France, and J. Dijkstra. 1999. A review of starch digestion in the lactating dairy cow and proposals for a mechanistic model: 1. Dietary starch characterisation and ruminal starch digestion. J. Anim. Feed Sci. 8:291-340.

Milton, C. T., R. T. Brandt Jr., and E. C. Titgemeyer. 1997. Effects of dietary nitrogen source and concentration in high-grain diets on finishing steer performance and nutrient digestion. J. Anim. Sci. 75:2813-2823.

Mitchell, P. L. 1997. Misuse of regression for empirical validation of models. Agric. Syst. 54:313-326.

Neter, J., M. H. Kutner, C. J. Nachtsheim, and W. Wasserman. 1996. Applied linear statistical models. 4th ed. McGraw-Hill Publishing Co., Boston, MA.

NRC. 1985. Ruminant nitrogen usage. National Academy Press, Washington, D.C.

NRC. 1989. Nutrient requirements of dairy cattle. 6th rev. ed. National Academy Press, Washington, D.C.

NRC. 2001. Nutrient requirements of dairy cattle. 7 th rev. ed. National Academy Press, Washington, D.C.

Odle, J., and D. M. Schaefer. 1987. Influence of rumen ammonia concentration on the rumen degradation rates of barley and maize. Br. J. Nutr. 57:127-138.

Olson, K. C., R. C. Cochran, T. J. Jones, E. S. Vanzant, E. C. Titgemeyer, and D. E. Johnson. 1999. Effects of ruminal administration of supplemental degradable intake protein and starch on utilization of low-quality warm-season grass hay by beef steers. J. Anim. Sci. 77:1016-1025.

Oosting, S. J., and A. Waanders. 1993. The effect of rumen ammonia nitrogen concentration on intake and digestion of wheat straw by goats. Anim. Feed Sci. Tech. 43:31-40.

Ørskov, E. R. 1992. Protein Nutrition in Ruminants. 2nd Ed. Harcourt Brace Jovanovich, San Diego, CA.

Pell, A. N. and P. Schofield. 1993. Computarized monitoring of gas production to measure forage digestion in vitro. J. Dairy Sci. 76:1063-1073.

Pierce, W. C. and Haenisch, E. L. 1947. Quantitative Analysis. 3rd ed. John Wiley and Sons, New York, NY.

Roffler, R. E., and L. D. Satter. 1975. Relationship between ruminal ammonia and nonprotein nitrogen utilization by ruminants. II. Application of published evidence to the development of a theoretical model for predicting nonprotein nitrogen utilization. J. Dairy Sci. 58:1889-1898.

Ruiz, R., G. L. Albrecht, L. O. Tedeschi, G. Jarvis, J. B. Russell, and D. G. Fox. 2001. Effect of monensin on the performance and nitrogen utilization of lactating dairy cows consuming fresh forage. J. Dairy Sci. 84:1717-1727.

Russell, J. B., J. D. O'Connor, D. G. Fox, P. J. Van Soest , and C. J. Sniffen. 1992. A net carbohydrate and protein system for evaluating cattle diets: I. Ruminal Fermentation. J. Anim. Sci. 70:3551-3561.

Russell, J. B. and H. J. Strobel. 1993. Microbial energetics. Pages 165186 in Quantitative Aspects of Rumen Digestion and Metabolism. J. M. Forbes and J. France, ed., CAB International, Oxon, United Kingdom.

Sarraseca, A., E. Milne, M. J. Metcalf, and G. E. Lobley. 1998. Urea recycling in sheep: effects of intake. Br. J. Nutr. 79:79-88.

SAS. 1999. SAS/STAT User's Guide, Version 8 edition. SAS Inst. Inc., Cary, NC.

Satter, L. D., and L. L. Slyter. 1974. Effect of ammonia concentration on rumen microbial protein production in vitro. Br. J. Nutr. 32:199-208.

Schofield, P., and A. N. Pell. 1994. Kinetics of fiber digestion from in vitro gas production. J. Anim. Sci. 72:2980-2991.

Schofield, P., and A. N. Pell. 1995. Measurement and kinetic analysis of the neutral detergent-soluble carbohydrate fraction of legumes and grasses. J. Anim. Sci. 73:3455-3463.

Siddons, R. C., J. V. Nolan, D. E. Beever, and J. C. MacRae. 1985. Nitrogen digestion and metabolism in sheep consuming diets containing contrasting forms and levels of N. Br. J. Nutr. 54:175-187.

Sniffen, C. J., J. D. O'Connor, P. J. Van Soest, D. G. Fox, and J. B. Russell. 1992. A net carbohydrate and protein system for evaluating cattle diets: II. Carbohydrate and protein availability. J. Anim. Sci. 70:3562-3577.

Tedeschi, L. O., D. G. Fox, and J. B. Russell. 2000. Accounting for the effects of a ruminal nitrogen deficiency within the structure of the Cornell Net Carbohydrate and Protein System. J. Anim. Sci. 78:1648-1658.

Van Kessel, J. S., and J. B. Russell. 1996. The effect of amino nitrogen on the energetics of ruminal bacteria and its impact on energy spilling. J. Dairy Sci. 79:1237-1243.

Van Soest, P. J. 1994. Nutritional Ecology of the Ruminant. 2nd Ed. Cornell University Press., Ithaca, NY.

Van Soest, P. J., J. B. Robertson, and B. A. Lewis. 1991. Methods for dietary fiber, neutral detergent fiber, and nonstarch polysaccharides in relation to animal nutrition. J. Dairy Sci. 74:3583-3597.

Van Soest, P. J., M. E. Van Amburgh, and L. O. Tedeschi. 2000. Pages 150-166 in Rumen balance and rates of fiber digestion. Proc. Cornell Nutr. Conf. Feed Manuf., Cornell University, Ithaca, NY. 